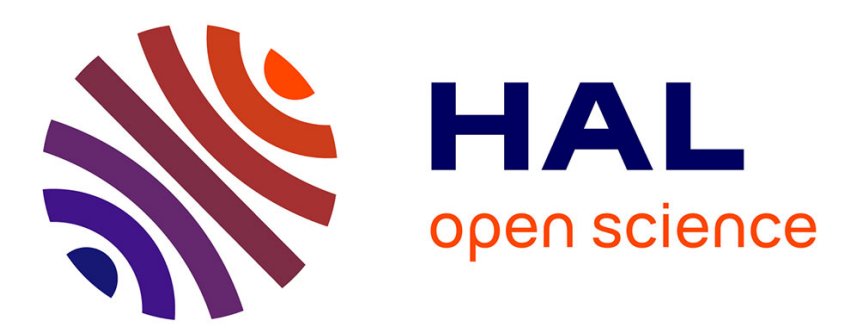

\title{
Microstructural characterization of a silicon carbide whisker reinforced 2014 aluminum metal matrix composite
}

\author{
E. Quadrini
}

\section{- To cite this version:}

E. Quadrini. Microstructural characterization of a silicon carbide whisker reinforced 2014 aluminum metal matrix composite. Journal de Physique IV Proceedings, 1993, 03 (C7), pp.C7-1741-C7-1744. 10.1051/jp4:19937274 . jpa-00251915

\section{HAL Id: jpa-00251915 https://hal.science/jpa-00251915}

Submitted on 1 Jan 1993

HAL is a multi-disciplinary open access archive for the deposit and dissemination of scientific research documents, whether they are published or not. The documents may come from teaching and research institutions in France or abroad, or from public or private research centers.
L'archive ouverte pluridisciplinaire HAL, est destinée au dépôt et à la diffusion de documents scientifiques de niveau recherche, publiés ou non, émanant des établissements d'enseignement et de recherche français ou étrangers, des laboratoires publics ou privés. 


\title{
Microstructural characterization of a silicon carbide whisker reinforced 2014 aluminum metal matrix composite
}

\author{
E. QUADRINI
}

Department of Mechanics, University of Ancona, Via Brecce Bianche, 60131 Ancona, Italy

\section{ABSTRACT}

Microstructural development in a powder metallurgy 2014 aluminum alloy - SiC whisker composite subject to controled and systematic aging treatments was investigated using analytical transmission electron microscopy and matrix microhardness measurements. In order to build a basis for comparison, the precipitation characteristics of the unreinforced matrix material with an identical processing history were also examined .

The results indicate that the matrix of the composite material has a much greater density of dislocations than the control alloy. This high density of dislocations is due to the substantial difference on thermal expansion of $\mathrm{Al}$ matrix with respect to the $\mathrm{SiC}$ particles.

\section{INTRODUCTION}

Metal matrix composites (MMCs) are very interesting because they offer the opportunity to obtain a material which combines the high tensile strength of fibers with the low density of a metals such as aluminum-alloys.In addition, because the reinforcement in the composite has a relatively high melting point, barring degradation of the fiber by chemical interaction with the matrix the strength properties of the composite can be retained at relatively high temperatures (1-3). Unfortunately the metal matrix composite haveyet found limited commercial applications mainly due to their low fracture toughness (4-6). This low toughness depend by thermal stresses due to the differential in the expansion coefficients of fiber and matrix can attain unacceptable levels in (MMCs). The pourpose of this paper is to present the results of a thorough microstructural characterization designed to examine the structure of the 20 vol\% SiCw/ $2014 \mathrm{Al}$ (T6) metal matrix composite by using microhardness measurements and TEM analisys. 


\section{EXPERIMENTAL PROCEDURE}

The chemical composition of metal-matrix composite contained $20 \mathrm{vol} \%$ silicon carbide whiskers is reported in Tab.I.

Tab. I. Chemical composition (wt\%)

$\begin{array}{llll}\mathrm{Cu} & \mathrm{Si} & \mathrm{Mn} & \mathrm{Mg} \\ 4.4 & 0.8 & 0.78 & 0.5\end{array}$

Before subsequent tests and observation, all the specimens were solution treated in an anhydrous nitrogen atmosphere at a temperature of $500^{\circ} \mathrm{C}$ for 3 hours and water quenched at room temperature; in order to prevent natural ageing fo the composite, the specimens were kept at - $20^{\circ}$ Subsequently, different microstructures were obtained ageing $\mathrm{MMC}$ samples in a thermostatically controlled silicone-based both at temperature of $145^{\circ}, 160^{\circ}, 180^{\circ}$ and $195^{\circ} \mathrm{C}$, with times ranging from 1 to 280 hours.

After ageing treatment, the specimens were rapidly cooled in water at room temperature and then tested with microhardness measurements.

\section{RESULTS AND DISCUSSION}

In Figs. 1 and 2 are reported respectively, at different temperatures, the microhardness values of metal matrix as a function of ageing time for alloy with and without reinforce. The curves show that the necessary time to reach the maximum hardness peak decreases with increasing the ageing temperatures; moreover this effect is enhanced int he case of renforced alloy.

This behaviour is related to different kinetics of the ageing process, investigated by Transmission Electron Microscopy.In both alloys at low ageing temperature, the presence of $\mathrm{GP}$ zone and $\mathrm{S}^{\prime}$ phase precipitates $\left(\mathrm{Al}_{2} \mathrm{CuMg}\right)$ is revealed.

The phase $S^{\prime}$ volume fraction, responsible of the hardening is much larger in the renforced alloy, due to the great number of dislocations present at the interface between the matrix and the surface; wich for the S' phase, represent preferential sites of heterogeneous nucleation. 


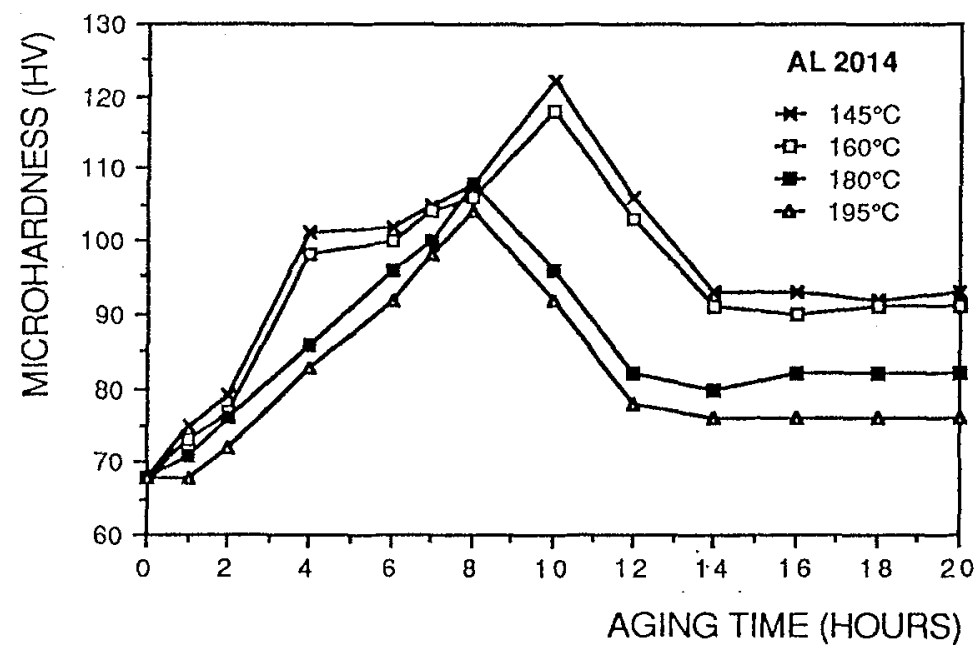

Fig. 1 variation in matrix microhardness for alloy without reinforce as a function of aging time at different temperatures.

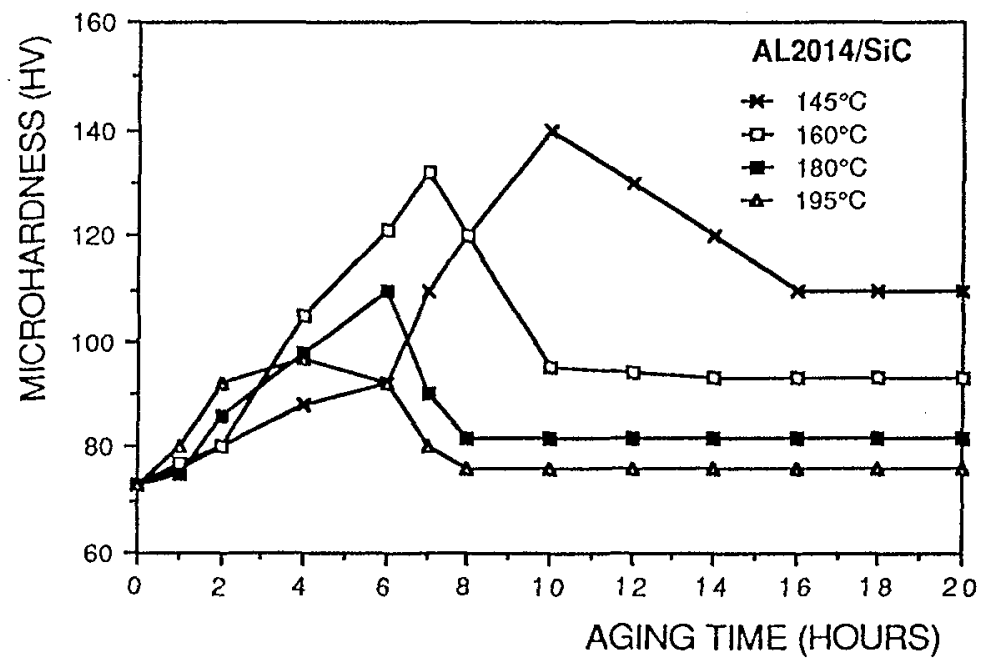

Fig. 2 variation in matrix microhardness for alloy with reinforce as a function of aging time at different temperatures. 
This seems to be the reason why the hardness peak is reached faster in the reinforced alloy than in the matrix. This behaviour result more markedly at high ageing temperatures.

In fact, increases the ageing temperature, the GP zones nucleation is obstructed of the microvoids produced during the cooling process. The presence of microvoids into the metallic structure favoured the dislocations formation and consequently the $S^{\prime}$ phase precipitation.

\section{CONCLUSIONS}

By comparing the results of the experimental tests of the investigation on the ageing kinetics of the alloy $\mathrm{Al} 2014$ and of that renforced with whiskers $\mathrm{Al}_{2} \mathrm{O}_{3}$, a substantial difference of the ageing time necessary to two samples to reach the maximum hardness peak is evidenced.

In fact, the time necessary, to the renforced alloy to reach the hardness peak is shorter and this difference increases with the ageing time.

This difference in the ageing kinetics, is related to different thermal expansion coefficients between the fibers and the matrix, and forms, at the fiber-matrix interface, the formation of the a high number of dislocations which act as preferencial sites for the $S^{\prime}$ phase nucleation, responsable of the alloy hardening.

\section{REFERENCES}

I 1 I DI CARLO J.A., J. Met. 37, (1985), 44.

I 2 I MC DANELS D.L., Met Trans. A, 16A, (1985), 1105.

I 3 I LE FLOUR J.C. and LOCICERO R., Scripta Metall., 18 , (1987), 773.

I 4 I VOGELSANG M. and FISHER R.M., Metall. Trans., 17, (1986), 379.

I 5 I Mc KIMPSON M.G. and SCOTT T.E., Mat. Sci.Eng., 107, (1989), 93.

I 6 I CHRISTMAN T. and SURESH S., Mat. Sci. Eng., 107, (1989), 49. 